\title{
Generation, Gender and Knowledge Gap in Agrobiodiversity Among Smallholders in Nepal
}

\author{
Pashupati Chaudhary ${ }^{1}$, Deepak Upadhya ${ }^{2}$, Bishnu Dhakal $^{3}$, Rajeev Dhakal ${ }^{4} \&$ Devendra Gauchan $^{5}$ \\ ${ }^{1}$ Agriculture and Forestry University, Rampur, Chitwan, Nepal \\ ${ }^{2}$ World Wildlife Fund, Baluwatar, Kathmandu, Nepal \\ ${ }^{3}$ Local Initiatives for Biodiversity, Research and Development, Pokhara, Nepal \\ ${ }^{4}$ Department of Plant Science, College of Agriculture and Bioresources, University of Saskatchewan, Saskatoon, \\ Saskatchewan, Canada \\ ${ }^{5}$ Alliance of Bioversity International \& CIAT, Kathmandu, Nepal \\ Correspondence: Pashupati Chaudhary, Agriculture and Forestry University, Rampur, Chitwan, Nepal. Tel: \\ 977-981-722-8956. E-mail: pashupatic@hotmail.com
}

Received: June 19, 2020

doi:10.5539/jas.v12n9p62
Accepted: August 1, $2020 \quad$ Online Published: August 15, 2020

URL: https://doi.org/10.5539/jas.v12n9p62

The research was financed by the Swiss Development Cooperation through Bioversity International and implemented by Local Initiatives for Biodiversity, Research and Development (LI-BIRD) and Nepal Agricultural Research Council (NARC), Nepal.

\begin{abstract}
The importance of generation-old local knowledge in advancing agriculture is well recognized worldwide. However, such knowledge is continually eroding together with the extinction of locally evolved genetic materials. Consequently, the knowledge gap between different age groups is widening. The knowledge gap is also widening between male and female due to continuous shift in gender roles in agriculture. Using responses collected from 120 male and female farmers from Bara, the lowland Terai of Nepal, we assessed inter-generational and gender-based knowledge gap of smallholders on agricultural biodiversity by taking rice crop as an example. Based on the standard definition of younger and older generation, the age group was divided into two: $\leq 34$ (15-34) years old and $>34$ years old. Information was collected on: i) rice varieties recalled by respondents, ii) rice varieties recognized by observing standing crop on-farm, iii) rice varieties recognized by observing seed samples, and iv) respondent's experiences and knowledge about selected cultivars. Descriptive analysis, t-test, and Pearson's Correlation were used to analyze the data. Respondents of age group $>34$ years old named and identified significantly $(\mathrm{p}<0.01)$ more varieties than age group $\leq 34$ in overall, indicating that the older generation is more knowledgeable and the knowledge hasn't been adequately inherited to younger generations resulting in the erosion of knowledge. Similarly, males are significantly more knowledgeable than females in overall and among the higher age group category $(\mathrm{p}<0.01)$, likely because males from Madhesi community have wider social networks both within and outside their villages than females. Females are more knowledgeable than males in the lower age group category because girls are engaged more in household chores and farming activities, while boys attain higher grades and travel for off-farm jobs. There was a strong correlation among the three techniques, namely, naming, recognizing standing crops, and recognizing the seeds $(p<0.01)$. This suggests that all the techniques are robust and can be interchangeably used for such type of studies depending on time and resource availability. This study finally infers that proper knowledge transfer is necessary to reduce the gulf of the knowledge gap between males and females as well as between generations if agrobiodiversity is to be conserved and utilized for growth and development of agriculture in the long run.
\end{abstract}

Keywords: genetic erosion, intergenerational knowledge gap, gender, agrobiodiversity, variety

\section{Introduction}

Agrobiodiversity contributes a range of goods and services to people for maintaining food and livelihood security, family nutrition, climate change adaptation, resilience and mitigation, ecological resilience, and 
environmental sustainability, mainly in diversity-rich but economically deprived countries (Altieri, 1999; Bellon et al., 2015; FAO, 2011; Jarvis et al., 2007; Mijatovic et al., 2013; UNEP, 2008; Vanek \& Drinkwater, 2013; Zimmerer, 2013). Current diversity is the function of natural selection, unconscious and conscious selection of farmers using their intricate knowledge, wisdom, and experiences over time, and deliberate selection of plant breeders (Brown, 2010; Frankel et al., 1995; Paroda \& Arora, 1991). Continuous selection, on-farm conservation, effective management and appropriate utilization of a diverse portfolio of agrobiodiversity is necessary for sustainably maintaining food security (CBD, 1992; Chaudhary \& Sthapit, 2013).

Traditional knowledge on agrobiodiversity plays a critical role in creating, managing and utilizing agricultural biodiversity, which eventually contributes to improved food security and resilience (Das \& Laub, 2005). The extent and use of traditional knowledge among people vary with gender and age group. Evidence shows that women hold more knowledge of seeds selection, preservation as compared to men (Fernandez \& Tick, 1994; Gurung, 1998; Subedi et al., 2003). Proper knowledge transfer to future generations is necessary to achieve long-term food security and sustainable livelihoods, alleviate poverty (Vealdi, 2008; Regidor, 2012) and protect indigenous rights (WIPO, 2009). Despite this fact, the interest of younger generations in agriculture has declined because they regard the agricultural jobs untidy, dangerous and difficult in comparison to the white-collar work with higher income (Osawa, 2014). Furthermore, the interest in growing local cultivars is declining partly because knowledge about their importance is not properly transferred to younger generations. As a result, agrobiodiversity is continually eroding from cultivable areas and associated knowledge about its use and maintenance is also disappearing together with the materials (Das \& Laub, 2005; Jarvis et al., 2007). Socio-culturally and ecologically important local cultivars are being replaced by modern varieties (Chaudhary et al., 2004; Gauchan et al., 2005), whose performance hinges on expensive and ecologically detrimental external inputs like fertilizer and pesticides. Such genetic erosion is exacerbating food insecurity among already food-insecure people, mainly the smallholders owning little lands and having poor access to agricultural inputs. This is also causing negative consequences on the environment and posing questions on its sustainability (Chhetri \& Chaudhary, 2011).

Knowledge systems are dynamic. People adapt to changes in their environment and absorb and assimilate ideas from a variety of sources (FAO, 2005). During the process of adaptation and absorption to changing environments in different agroecosystems and local socioeconomic setting, the knowledge system differs by gender and generation. Evidence shows that indigenous knowledge and gender are inextricably bound up with each other and the knowledge and skills held by women often differ from those held by men (Fernandes \& Tick, 1994). With experience and time, the knowledge system also differs among different age groups. It is important to understand the knowledge gap and develop appropriate strategies to reduce the gap thus aiding in the conservation of valuable agrobiodiversity and improving food security in the long run. The knowledge gap study can help identify how knowledge is distributed among different age and gender groups, which will help identify target populations and plan technology diffusion activities. The local operational knowledge study also helps monitor biodiversity and ecosystem services (Jackson et al., 2012), identify appropriate remedies and keep farmers interest abreast. To date, very few studies have been conducted on this front and previous studies have used anecdotal information collected from a small fraction of populations and are likely manifested by researchers' biased judgment. Such studies also don't allow to quantitatively measure the knowledge gap. Zimmerer (2013) has used quantitative methods to understand the knowledge gap between migrant and non-migrant people in Bolivia and has found no significant difference in their level of knowledge. Several studies identified the root causes of traditional knowledge erosion, which includes the adoption of modern intensive agricultural practices using high-yielding hybrid plant varieties (Fenta, 2000; Le-Quy, 2004), displacement of communities owing to massive logging and mining projects (Blanco, 2004) and waning interest by the younger generation (Sahai, 2003). However, there is rarely any studies found which quantify the inter-generational and gender-wise knowledge gap.

This paper examines an intergenerational and gender-wise knowledge gap on agricultural biodiversity, taking rice as an example, in a farming community in Bara district of Nepal Terai, from the data gathered using four methods discussed later. The results of the three methods were compared to validate their robustness. We also offer strategies to reduce the knowledge gap for conserving local cultivars aiming at enhancing food security and environmental sustainability. 


\section{Methodology}

\subsection{Study Sites}

The study was conducted in two villages (Kachorwa and Paterwa) in the Gadhimai rural municipality of Bara districts of Nepal Terai (the Indogangetic plains) bordering to India, where there is a predominance of Madhesi community. The Madhesi are the lowland people of diverse ethnic/caste groups leaving in the Terai region of Nepal with predominantly of Hindu religious background.The study sites are situated at a latitude of $26^{\circ} 52^{\prime} 5.56^{\prime \prime}$ to $26^{\circ} 56^{\prime} 30.23^{\prime \prime} \mathrm{N}$ and a longitude of $85^{\circ} 8^{\prime} 36.02^{\prime \prime}$ to $85^{\circ} 11^{\prime} 22.08^{\prime \prime} \mathrm{E}$ and at an elevation of 80-90 masl. Rice is the principal crop grown in the area during the rainy season followed by wheat, mustard, lentils and vegetables in the winter. In Kachorwa, the Local Initiatives for Biodiversity, Research and Development (LI-BIRD), an NGO and the Nepal Agricultural Research Council (NARC) have been implementing agrobiodiversity conservation work since 1998 with the support of Bioversity International, but there is no such intervention in Paterwa. The two sites are adjoining villages, located about 27-30 kilometers from the district headquarters, Kalaiya, and accessible through graveled road running along the Gandak irrigation canal. Socioeconomic, cultural and biophysical conditions of both the VDCs are similar, with entirely Madhesi ethnic group predominated by Yadav, Sah (teli and kanu), Koiri and few so-called untouchable castes such as Musahar, Dom, Chamar, Dusadh and so forth dwelling in both the VDCs. The basic characteristics of the study villages are presented in Table 1 below.

Table 1. Socioeconomic, demographic and geographic condition of project sites

\begin{tabular}{|c|c|c|}
\hline VDC & Paterwa & Kachorwa \\
\hline Total Population* & 3999 & 10,958 \\
\hline Total Household* & 617 & 1,614 \\
\hline Altitude $(\mathrm{m})^{\#}$ & $85-90$ & $80-90$ \\
\hline Longitude $^{\#}$ & $85^{\circ} 09^{\prime} 59.60^{\prime \prime}$ to $85^{\circ} 11^{\prime} 22.08^{\prime \prime} \mathrm{E}$ & $85^{\circ} 8^{\prime} 36.02^{\prime \prime}$ to $85^{\circ} 10^{\prime} 43.04^{\prime \prime} \mathrm{E}$ \\
\hline Latitude $^{\#}$ & $26^{\circ} 55^{\prime} 46.69^{\prime \prime}$ to $26^{\circ} 56^{\prime} 30.23^{\prime \prime} \mathrm{N}$ & $26^{\circ} 52^{\prime} 5.56^{\prime \prime}$ to $26^{\circ} 54^{\prime} 6.75^{\prime \prime} \mathrm{N}$ \\
\hline Type of road & Unmetalled (Rough) & Unmetalled (Rough) \\
\hline Accessibility (km from HQ)^ & $30 \mathrm{~km}$ & $27 \mathrm{Km}$ \\
\hline Total Area (ha) ${ }^{* *}$ & 725 & 840 \\
\hline Overall Development Index ${ }^{\mathrm{O}}$ & 55 & 55 \\
\hline
\end{tabular}

District development index position among 75 districts

Source: * Indicates data taken from the National Population and Housing Census 2011 (Village Development Committee/Municipality); ${ }^{\#}$ Indicates data taken from Google earth; ${ }^{* *}$ VDC and demographic profile of Nepal 2013; ${ }^{\wedge}$ Indicates data derived from FGD and survey conducted in Bara; ${ }^{\mathrm{O}}$ Indicates data taken from CBS.

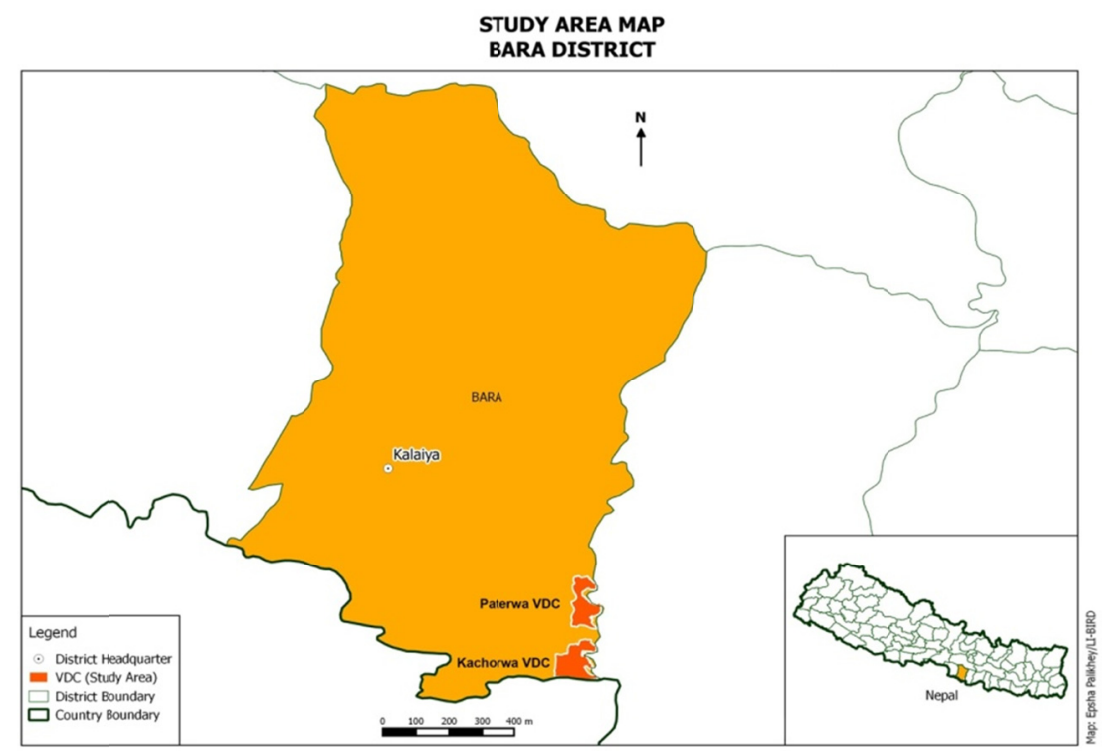

Figure 1. Map of study area showing Bara district and two villages 


\subsection{Sampling Design}

Altogether 120 individuals were selected from the two villages using a simple random sampling technique, making sure there were an equal number of households from each village. While selecting the sample, age and gender issues were taken into consideration. Half of the respondents were male and the other half were female. Similarly, 60 were between $\leq 34$ (15-34) years old (youth category) and 60 were $>34$ years old, which is half of the average life expectancy in Nepal. Furthermore, Gale et al. (2013) and European Communities (2012) in their study considered the youth population to be aged under 35. Moreover, the life expectancy of Bara district in Nepal is 70.5 (GoN 2014) and 34 if just below the half (35) of it. Hence, the final sample was of four types: male age between $\leq 34$ years $(n=30)$, female between $\leq 34$ years old $(n=30)$, males older than 34 years $(n=30)$ and females $>34$ years $(n=30)$. This is also depicted in Figure 2 below.

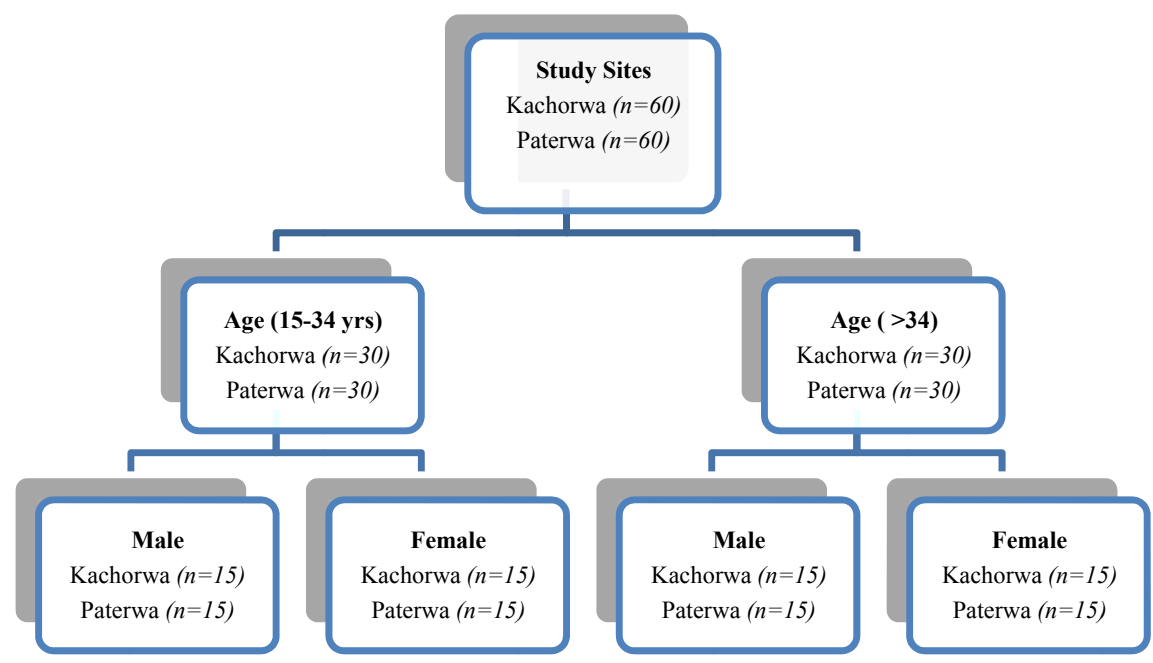

Figure 2. Diagram describing the sampling technique

\subsection{Data Collection Method}

For data collection, we used four types of tools. First, the respondents were asked to recall and name of rice varieties they know about, which was recorded on a data sheet. Second, they were taken to a Diversity Block maintained to regenerate and disseminate the seeds of local varieties conserved in the Community Seed Bank (CSB) to increase the portfolio of locally adaptive crop varieties. A total of 33 landraces from the available portfolio of the CSB was planted in $1 \mathrm{~m}^{2}$ plot each. The respondents were asked to identify the varieties grown in the diversity block and the numbers of correct and incorrect answers were derived from their response. Third, following the variety identification test on the diversity block, the respondents were taken to a stall where the seeds of the same set of varieties included in the diversity block were displayed. The respondents were again asked to identify the varieties displayed there and that was recorded on a data sheet. For both diversity block and spotting exercise, the respondents were given two options: write the name of the variety if they feel they know it, or tick on 'don't know the name'. If they named, that was either correct or incorrect which was verified later using the codes given for each variety. Only one respondent was allowed at a time and they were asked to leave the place once they attended to prevent leaking of information. Fourth, we interviewed the respondents to learn more about their knowledge on local landraces against four criteria: (i) they have/haven't heard the landrace; (ii) if heard, they have seen/not seen it; (iii) if seen, they have eaten/not eaten it; and (iv) if eaten, they have grown/not grown the variety themselves.

\subsection{Data Analysis Techniques}

The level of knowledge of the respondents was assessed based on their ability to recall the rice varieties, their ability to identify the rice varieties in the diversity block and on the spotting, and their responses over the four criteria used to test their knowledge (heard or not, seen or not, eaten or not, planted or not). We counted the number of varieties recalled, the right answers given by them in the diversity block (Note 1) test and spotting test, and the number of 'yes' answers given by the respondents to the fourth technique. Then the data were interpreted with the assumption that the higher the number recalled and the more the right answers, the higher the level of knowledge. We analyzed the data using descriptive analysis, independent t-test, and correlation. The 
disintegration of data was done based on age group and gender, to observe the knowledge gap between different age groups and between men and women Knowledge gap of men and women was also measured within the same age group category. The comparison was done on the following bases: male versus female as a whole, male versus female in age group $\leq 34$, male versus female in age group 34 and above, age group $\leq 34$ versus above 34 as a whole, age group 15-34 versus above 34 among male, and age group $\leq 34$ versus above 34 among female. A T-test was used mainly to compare responses between men and women and between two age group categories. The correlation was used to compare the first three methods in order to validate their robustness and resemblance in the findings.

\section{Findings}

\subsection{Knowledge Gap in Recalling Rice Varieties}

When respondents were asked to identify varieties in the diversity block, different of them identified different number of varieties. The respondents from age group $\leq 34$ years recalled on average 5.20 cultivars while the respondents from age group $>34$ years recalled 7.83 varieties, and the difference between the two age groups is statistically significant. Similarly, males recalled significantly more cultivars (7.13) than females (5.9) when both age groups are combined $(\mathrm{p}<0.1)$. Among males alone, younger respondents recalled significantly fewer cultivars (4.83) than older age respondents $(9.43)(\mathrm{p}<0.01)$; on contrast, among female alone, younger respondents recalled more cultivars (6.23) than older aged females (5.57) but not at statistically significant level. Within younger age group respondents, males recalled fewer varieties (4.83) than females (5.57), but not at a significant level, whereas among older people males recalled more varieties $(9.43)$ than females $(6.23)(p<0.01)$ These results are also presented in Table 2 below.

Table 2. The mean number of rice variety recalled by different age categories and gender

\begin{tabular}{lllll}
\hline Age group category & Overall & Male & Female & t-statistics \\
\hline Overall & NA & $7.13(3.99)$ & $5.9(3.51)$ & $1.798^{*}$ \\
Age $\leq 34$ & $5.20(2.78)$ & $4.83(1.84)$ & $5.57(3.47)$ & -1.022 \\
Age $>34$ & $7.83(4.22)$ & $9.43(4.24)$ & $6.23(3.58)$ & $3.155^{* * *}$ \\
\hline t-statistics & $-4.04^{* * * * *}$ & $-5.442^{* * *}$ & -0.732 & NA \\
\hline
\end{tabular}

Note. Figures in parentheses are standard deviation; *** significant at $0.01, * *$ significant at 0.05 and * significant at 0.1 .

\subsection{Knowledge in Identification of varieties in Diversity Block}

The knowledge assessed through recognizing varieties in Diversity Block showed that different individuals identified different varieties and different individuals had different numbers of correct answers. Overall, respondents from age group $\leq 34$ years gave correct answers (recognized) on average to 1.43 cultivars and those from $>34$ age group recognized a significantly higher number of cultivars $(3.18)(p<0.01)$. Similarly, males recognized fewer cultivars (2.22) than females (2.4) on average but not at a statistically significant level. Moreover, among younger respondents, males recognized fewer cultivars (1.07) than females $(1.8)(p<0.1)$ and among older age respondents, males recognized more cultivars (3.37) than females (3), but not at a statistically significant level. Among males, younger respondents recognized significantly fewer cultivars (1.07) than older age respondents (3.37) and among females, younger respondents recognized significantly more cultivars (3.0) than older age respondents $(1.8)(\mathrm{p}<0.01)$.

Table 3. Mean number of correct answers on DB test by different age category and gender

\begin{tabular}{lllll}
\hline Age group category & Overall & Male & Female & t-statistics \\
\hline Overall & & $2.22(2.02)$ & $2.4(1.65)$ & -0.55 \\
Age $\leq 34$ & $1.43(1.53)$ & $1.07(1.39)$ & $1.8(1.61)$ & $-1.892^{*}$ \\
Age $>34$ & $3.18(1.70)$ & $3.37(1.9)$ & $3.0(1.49)$ & 0.832 \\
\hdashline t-statistics & $-5.92^{* * *}$ & $-5.35^{* * *}$ & $-3.004^{* * * * *}$ & \\
\hline
\end{tabular}

Note. Figures in parentheses are standard deviation; *** significant at $0.01, * *$ significant at 0.05 and * significant at 0.1 . 


\subsection{Knowledge in Identification of Varieties in Spotting}

The knowledge in identifying varieties displayed in the spotting was also assessed using the number of correct answers given by the respondents. Overall, younger respondents recognized 0.82 cultivars and older age respondents recognized 2.32 cultivars, and the difference in number is statistically significant $(\mathrm{p}<0.05)$. Similarly, males recognized 1.48 cultivars and females recognized 1.65 cultivars, which was not statistically significant. Among younger respondents, males recognized significantly fewer cultivars (0.4) than females (1.23) $(\mathrm{p}<0.01)$ and among older age respondents, males recognized more cultivars $(2.57)$ than females $(2.07)$ but not statistically significant level. Among males, younger respondents recognized significantly fewer cultivars (0.4) than older age respondents $(2.57)(\mathrm{p}<0.01)$. Among females, older respondents recognized significantly more cultivars $(2.07)$ than younger ones $(1.23)(\mathrm{p}<0.05)$.

Table 4. Mean number of correct answers on spotting test by different age category and gender

\begin{tabular}{lllll}
\hline Age group category & Total & Male & Female & t-statistics \\
\hline Total & & $1.48(1.63)$ & $1.65(1.34)$ & -0.61 \\
Age $\leq 34$ & $0.82(1.16)$ & $0.4(0.77)$ & $1.23(1.33)$ & $-2.97^{* * *}$ \\
Age $>34$ & $2.32(1.41)$ & $2.57(1.55)$ & $2.07(1.23)$ & 1.39 \\
\hline t-statistics & $6.38^{* *}$ & $-6.869^{* * *}$ & $-2.52^{* * *}$ & \\
\hline
\end{tabular}

Note. Figures in parentheses are standard deviation; *** significant at $0.01, * *$ significant at 0.05 and * significant at 0.1 .

\subsection{Experiences with Local Varieties}

Four techniques were used to assess how knowledgeable respondents were on different rice varieties as discussed in the methodology. In all four techniques, older age respondents have outperformed the younger respondents. For instance, older age males have heard significantly more number of the cultivars (included in the test than the older age females $(\mathrm{p}<0.01)$. Whereas males have outperformed females in the age group $>34$, but females have outperformed males in the age group 15-34 for all three parameters used. For instance, in the age group 15-34, females have heard more varieties than males $(p<0.1)$ and in the age group $>34$, males have heard about more number of varieties than females $(\mathrm{p}<0.05)$. Additional details are presented in Table 5 .

Table 5. Age and gender-wise comparison for general experiences on local varieties

\begin{tabular}{|c|c|c|c|c|c|c|c|c|c|c|c|c|}
\hline \multirow[t]{2}{*}{ Age category } & \multicolumn{3}{|c|}{ Heard about the variety } & \multicolumn{3}{|c|}{ Seen the variety } & \multicolumn{3}{|c|}{ Eaten the variety product } & \multicolumn{3}{|c|}{ Cultivated the variety him/herself } \\
\hline & Male & Female & t-stat & Male & Female & t-stat & Male & Female & t-stat & Male & Female & t-stat \\
\hline Age $\leq 34$ & $\begin{array}{l}7.3 \\
(5.67)\end{array}$ & $\begin{array}{l}9.87 \\
(5.95)\end{array}$ & $-1.71^{*}$ & $\begin{array}{l}4.83 \\
(3.75)\end{array}$ & $\begin{array}{l}7.83 \\
(5.63)\end{array}$ & $-2.43^{* *}$ & $\begin{array}{l}2.83 \\
(1.77)\end{array}$ & $\begin{array}{l}6.07 \\
(5.18)\end{array}$ & $-3.19^{* * *}$ & $\begin{array}{l}2.74 \\
(1.77)\end{array}$ & $\begin{array}{l}4.93 \\
(4.01)\end{array}$ & $-2.6^{* *}$ \\
\hline Age $>34$ & $\begin{array}{l}17.63 \\
(5.5)\end{array}$ & $\begin{array}{l}13.53 \\
(6.85)\end{array}$ & $2.56^{* *}$ & $\begin{array}{l}14.37 \\
(6.96)\end{array}$ & $\begin{array}{l}10.77 \\
(5.48)\end{array}$ & $2.28^{* *}$ & $\begin{array}{l}11.36 \\
(7.76)\end{array}$ & $\begin{array}{l}8.62 \\
(5.53)\end{array}$ & 1.54 & $\begin{array}{l}9.88 \\
(6.84)\end{array}$ & $\begin{array}{l}7.74 \\
(5.79)\end{array}$ & 1.21 \\
\hline t-stat & $-7.17^{* *}$ & $-2.21^{* * *}$ & & $-6.6^{* * *}$ & $-2.05^{* *}$ & & $-5.77^{* *}$ & $-1.83^{*}$ & & $-5.23^{* *}$ & $-2.1^{* *}$ & \\
\hline
\end{tabular}

Note. Figures in parentheses are standard deviation; *** significant at $0.01, * *$ significant at 0.05 and $*$ significant at 0.1 .

\section{Discussion}

Local knowledge is an integral part of agrobiodiversity conservation as farmers use locally evolved knowledge to deploy their varieties based on their local ecological suitability (Rana et al., 2007), select seed and planting materials for next seasons and store in appropriate ways to protect from adverse biotic and abiotic conditions (Bania et al., 2005). As local knowledge and scientific knowledge complement each other, blending the two types of knowledge systems is important for agrobiodiversity conservation and climate change resilience (Chaudhary \& Bawa, 2011; Rana et al., 2007). Berkes (2008) argues that amalgamation of knowledge, practice, and belief evolved over generations are inherited from generation to generation through a regular cultural transmission process. 
Scientists are increasingly studying local knowledge and the results are used to devise strategies for social resilience and for building adaptive human capacities against climate-induced shocks (Folke, 2006; Turner \& Clifton, 2009). Akullo et al. (2007) pointed out that indigenous knowledge and practices are useful in improving yields, preventing crop pests and diseases, and treating livestock diseases. They also suggest that such knowledge be integrated into contemporary research to enable farmers respond to global agriculture and climate change challenges. Despite this fact, such knowledge is not taken into account in most of the adaptation work (Cote \& Nightingale, 2012; Ribot, 2010), and as a result, local knowledge is eroding together with the loss of local varieties, limiting the future options for developing new varieties (Friis-Hansen, 1999; Megersa, 2014) and weakening local adaptive capacity (Chhetri \& Chaudhary, 2011).

The recall method suggests that the younger generation is less knowledgeable than the elder generation, which indicates that all the knowledge is not adequately transferred to the younger generation. Gomez-Baggethun et al. (2010), Ogunbonde and Arnold (2012) and Singh et al. (2007) also discovered that older aged people hold significantly higher agricultural knowledge than younger aged people. This finding on inter-generational knowledge differences also corroborate with the finding of Hanazaki et al. (2013). Furthermore, inference of the inadequate transformation of traditional agricultural knowledge to the younger generation in this study resembles the finding of Agarwal (2002).

Gender-wise comparison results hint that males are more knowledgeable than females in general, and in the younger generation, girls are more knowledgeable than boys. This could be because males are more outgoing, have wider social networks and interact more with other fellow farmers both within the village and outside compared to females, while females are mostly confined within the house or villages with poorer network and mobility as compared to their male counterparts. This is particularly common in Terai (Madeshi) ethnic groups in Nepal due to their prevailing sociocultural system and norms that make them stay at home and take more roles of household chores (Bajracharya, 1994; Pradhan, 1984). Ogunbonde and Arnold (2012) also report that males have more knowledge about biodiversity than females. Subedi et al. (2003) suggest that there are more male custodian farmers than the females in Kachorwa and Begnas villages in Nepal and male members share seeds and related information more frequently as well as with more farmers than the females. However, at the lower age group, females in rural areas are more knowledgeable than males in agriculture and agrobiodiversity conservation because they stay at home and are more engaged in household chores and farming activities. This is because girls are either never enrolled in schools or even if enrolled, are forced to drop out at earlier ages, while boys receive higher education and travel for off-farm jobs.

Ijioma and Osondu (2015) suggest that longer the experiences of farming, more the farmer is proficient in using indigenous knowledge and practices. They, contrary to our finding, have also observed that female farmers are more efficient in using local knowledge and practices than male counterparts. Ekue et al. (2010) also observe variation in local knowledge on fruit traits among ethnic groups and gender groups. Poudel et al. (2004) look at the status of knowledge over time and concluded that certain knowledge holders remain the same, while others also emerge in the communities.

Our study indicates females among the age group 15-34 are more knowledgeable, which is likely because younger males continue to attend school while their girl siblings either never attend formal school or are forced to drop out in order to assist family in farm and household chores. Boys move outside their village for off-farm jobs, which takes them away from agricultural works, which results in poor upgrading of knowledge, ultimately leading to erosion of knowledge. In a similar study, Legesse et al. (2013) report that young males were found to be less knowledgeable than female counterparts because the former are increasingly engaged in off-farm activities since they attend school.

Diversity blocks are established to regenerate local variety seeds and improve knowledge among farmers about the varietal diversity and their characteristics, which is also part of knowledge transfer from one farmer to another, including knowledge inheritance from older age farmers to younger farmers. Many farmers also recognize varieties through seeds, and thus assessing their knowledge through seed observation is also equally valid. The number of varieties recalled shows a strong correlation with the number of correct answers given both in the diversity block and spotting $(\mathrm{p}<0.01)$. Similarly, the number of correct answers given in the diversity block is strongly correlated with the correct answers given in the spotting test $(p<0.01)$. Since the results obtained through all three methods corroborate (Table 6), these methods are robust and can be used interchangeably based on available time and financial resources, although knowledge assessment through observation of seed sample looks easy, quick, and cost-effective. 
Table 6. Relationship between number of varieties recalled and identified in diversity block and spotting (Pearson's Correlation)

\begin{tabular}{lll}
\hline Variables & Number of varieties recalled & $\begin{array}{l}\text { Number of varieties } \\
\text { identified in Diversity Block }\end{array}$ \\
\hline $\begin{array}{l}\text { Number of varieties recalled } \\
\text { Number of varieties identified in DB }\end{array}$ & $0.42^{* * *}$ & \\
Number of varieties identified in spotting & $0.418^{* * *}$ & $0.627^{* * *}$ \\
\hline
\end{tabular}

\section{Conclusion}

The findings of this study conclude that age and gender play an important role in management and usage of rice biodiversity in Nepal's Terai. Among different age groups, the older generation is more knowledgeable in naming and recognizing seeds and standing crop varieties, which means knowledge hasn't been adequately inherited to younger generations, or knowledge erosion is taking place. Similarly, male farmers are significantly knowledgeable than females in overall as well as among the higher age group category. Gender differences also exist in knowledge level at the lower age groups, where females are more knowledgeable than males. There was a strong correlation among the three techniques, namely, naming, recognizing standing crops, and recognizing seeds. This infers that proper knowledge transfer is necessary to reduce the knowledge gap between gender and generation if agrobiodiversity is to be conserved and utilized for growth and development of agriculture in the long run.

Although inter-generational as well as gender-wise knowledge gap is prevalent in intellectual discourse, empirical evidence was lacking. This study contributes to the ongoing debate, as it quantifies the knowledge gap between two age groups, and between two genders in general and their age groups. The results from this study reinforce the previous beliefs and arguments established based on anecdotal facts and figures that older age groups and younger females have more knowledge and expertise in identifying and conserving diverse crop varieties. Thus, it suggests that if this trend continues, knowledge about local crops, crop varieties, cultivation methods, and other associated knowledge and skills will also erode. Since the younger generation is less knowledgeable due to inadequate level of knowledge transfer, concerted efforts need to be made to train the younger generation in economic, ecological, and cultural values of local varieties, and encourage them in variery preservation. Similarly, older age females need more exposure and interactions with the fellow farmers, mainly male counterparts, to learn more about varieties. Otherwise, they will just continue the hard work but will be deprived of old as well as new knowledge. Moreover, young males need to be made aware of value and traits of local varieties so that their interests can be kept abreast in light of ongoing social and ecological paradigm shifts. Different methods can be used to assess knowledge based on available time and financial resource, but its basis should be periodic assessment of local knowledge and devising of appropriate strategies to retain and transfer knowledge to future generations for conservation of agrobiodiversity to bolster food security and climate change resilience in the future. This will require focused capacity enhancement, exposure visits, and increased awareness on varietal traits and their role in food production and conservation of agrobiodiversity. Therefore, targeting agricultural development and biodiversity conservation program must recognize gender-based and intergenerational knowledge and incorporate that in knowledge-generating, planning and policy making processes.

\section{References}

Agrawal, R. (2002). Small farms, women, and traditional knowledge: Experiences from Kumaon hills. 17th Symposium of the International Farming Systems Association, November 17-20, 2002, Lake Buena Vista, FL, USA. Retrieved from http://conference.ifas.ufl.edu/ifsa/papers/c/c1.docs

Akullo, D., Kanzikwera, R., Birungi, P., Alum, W., Aligurna, L., \& Barwogeza, M. (2007). Indigenous knowledge in agriculture: A case study of the challenges in sharing knowledge of past generations in a globalized context in Uganda.

Altieri, M. A. (1999). The ecological role of biodiversity in agroecosystems. Agriculture Ecosystems and Environment, 74, 19-31. https://doi.org/10.1016/S0167-8809(99)00028-6

An, L. Q. (2004). The Use and Commercialization [sic] of Genetic Resources and Traditional Knowledge in Vietnam: The Case of Crop and Medicinal Plants. In S. Twarog and P. Kapoor (Eds.), Protecting and Promoting Traditional Knowledge: Systems, National Experiences and International Dimensions (pp. 7-14). 
Bajracharya, B. (1994). Gender Issues in Nepalese Agriculture: A Review (Research Report No. 25). Winrock International, Kathmandu, Nepal.

Baniya, B. K., Tiwari, R. K., Chaudhary, P., Shrestha, S. K., \& Tiwari, P. R. (2005). Planting materials seed systems of finger millet, rice and taro in Jumla, Kaski and Bara districts of Nepal. Nepal Agriculture Research Journal, 6, 39-48. https://doi.org/10.3126/narj.v6i0.3343

Bellon, M. R., Gotor, E., \& Caracciolo, F. (2015). Conserving landraces and improving livelihoods: How to assess the success of on-farm conservation projects? International Journal of Agricultural Sustainability, 13(2), 167-182. https://doi.org/10.1080/14735903.2014.986363

Berkes, F. (2008). Sacred ecology (2nd ed.). London and New York: Routledge. https://doi.org/10.4324/9780203 928950

Bezner, R. K. (2014). Lost and Found Crops: Agrobiodiversity, Indigenous Knowledge, and a Feminist Political Ecology of Sorghum and Finger Millet in Northern Malawi. Annals of the Association of American Geographers, 104(3), 577-593. https://doi.org/10.1080/00045608.2014.892346

Blanco, J. L. B. (2004). Harnessing Traditional Knowledge for Development and Trade: The Philippines Experience. In S. Twarog and P. Kapoor (Eds.), Protecting and Promoting Traditional Knowledge: Systems, National Experiences and International Dimensions (pp. 293-298).

Brown, H. D. (2010). Variation under domestication in plants: 1859 and today. Philosophical Transactions of the Royal Society B: Biological Science, 365, 2523-2530. https://doi.org/10.1098/rstb.2010.0006

CBD (Convention on Biological Diversity). (1992). Handbook of the Convention on Biological Diversity. Routledge, London. https://doi.org/10.4324/9781315071770

Chaudhary, P., \& Bawa, K. S. (2011). Local perceptions of climate change validated by scientific evidence in the Himalayas. Biology Letters, 7(5), 767-770. https://doi.org/10.1098/rsbl.2011.0269

Chaudhary, P., \& Sthapit, B. (2013). Agricultural biodiversity conservation and food security for small-scale farmers. In A. Christinck \& M. Padmanabhan (Eds.), Cultivate Diversity-A handbook on trans-disciplinary approaches to agrobiodiversity research. Margraf Publishers, Scientific Books, Welkershelm, Germany.

Chaudhary, P., Gauchan, D., Rana, R. B., Sthapit, B. R., \& Jarvis, D. I. (2004). Potential loss of rice landraces from a Terai Community in Nepal: A case study from Kachorwa, Bara. Plant Genetic Resource Newsletter (p. 137). Rome: International Plant Genetic Resource Institute.

Chhetri, N., \& Chaudhary, P. (2011). Green revolution: Pathways to food security in an era of climate variability and change? Journal of Disaster Research, 6(5), 486-497. https://doi.org/10.20965/jdr.2011.p0486

Cote, M., \& Nightingale, A. J. (2012). Resilience thinking meets social theory: Situating social change in socioecological systems (SES) research. Progress in Human Geography, 36(4), 475-89. https://doi.org/ $10.1177 / 0309132511425708$

Das, S., \& Laub, R. (2005). Understanding links between gendered local knowledge of agrobiodiversity and food security in Tanzania. Mountain Research and Development, 25, 218-222. https://doi.org/10.1659/0276-4741 (2005)025[0218:ULBGLK]2.0.CO;2

Ekue, M. R. M., Sinsin, B., Eyog-Matig, O., \& Finkelde, R. (2010). Uses, traditional management, perception of variation and preferences in ackee (Blighia sapida K.D. Koenig) fruit traits in Benin: Implications for domestication and conservation. Journal of Ethnobiology and Ethnomedicine, 12(6). https://doi.org/ $10.1186 / 1746-4269-6-12$

European Communities. (2012). Generational renewal in EU agriculture: Statistical background. Brussels: European Commission, Directorates-General Agriculture and Rural Development. Retrieved September 12, 2015, from http://www.foropac.es/sites/default/files/documentos/RelevoGeneraPAC.pdf

FAO (Food and Agriculture Organization of the United Nations). (2005). Building on Gender, Agrobiodiversity and Local Knowledge-A Training Manual. Rome, Italy.

FAO (Food and Agriculture Organization of the United Nations). (2011). Biodiversity for food and Agriculture: Contributing to food security and sustainability in a changing world. The Food and Agriculture Organization (FAO) of the United Nations and the Platform for Agrobiodiversity Research. Outcomes of an expert workshop held by FAO and the Platform on Agrobiodiversity Research from 14-16 April 2010 in Rome, Italy. 
Fenta, T. (2000). An overview of Indigenous Knowledge practices in the Ethiopian farming systems. Proceeding of the workshop on First Annual meeting of the Association for the Promotion of Indigenous Knowledge, January 20, 2000, Addis Ababa, Ethiopia.

Fernandez, E. M., \& Tick, A. W. (1994). Gender and indigenous knowledge. Indigenous Knowledge and Development Monitor, 2(SP3).

Folke, C. (2006). Resilience: The emergence of a perspective for social-ecological analyses. Global Environmental Change, 16, 253-267. https://doi.org/10.1016/j.gloenvcha.2006.04.002

Frankel, O. H., Brown, A. H. D., \& Burdon, J. J. (1995). The conservation of plant biodiversity. Cambridge, UK: Cambridge University Press.

Friis-Hansen, E. (1999). Erosion of Plant Genetic Resources: Causes and effects. Danish Journal of Geography, $1,61-68$.

Gale, F., \& Fahey, S. (2013). Youth in Transition: The Challenges of Generational Change in Asia (pp. 1-275). Association of Asian Social Science Research Councils, UNESCO.

Gauchan, D., Smale, M., Maxted, N., Cole, M., Sthapit, B. R., Jarvis, D., \& Upadhyay, M. P. (2005). Socioeconomic and Agroecological determinants of conserving diversity on-farm: The case of Rice Genetic Resources in Nepal. Nepal Agriculture Research Journal, 6, 89-98. https://doi.org/10.3126/narj.v6i0.3370

Gomez-Baggethun, E., Mingorria, S., Reyes-Garcia, V., Calvet, L., \& Motes, C. (2010). Traditional ecological knowledge trends in the transition to a market economy: Empirical study in the Donana Natual Areas. Conservation Biology, 24, 721-729. https://doi.org/10.1111/ j.1523-1739.2009.01401.x

GoN (Government of Nepal). (2014). Nepal Human Development Report 2014 Beyond Geography, Unlocking Human Potential. Government of Nepal, National Planning Commission Singha Durbar and UNDP.

Gurung, J. (1998). Gender Dimension of Biodiversity Management: Cases from Bhutan and Nepal. Biodiversity Management in the Hindu-Kush Himalayas (ICIMOD Newsletter No. 31).

Hanazaki, N., Herbst, D. F., Marques, M. S., \& Vandebroek, I. (2013). Evidence of the shifting baseline syndrome in ethnobotanical research. Journal of Ethnobiology and Ethnomedicine, 9, 75-85. https://doi.org/ $10.1186 / 1746-4269-9-75$

Ijioma, J. C., \& Osondu, C. K. (2015). Indigenous Knowledge and Practices for Sustainable Conservation of Agro-Biodiversity by Farmers in Umuahia North Local Government Area of Abia State, Nigeria.

Jackson, M., Kennett, R., Weisenberger, F., Bayliss, P., \& Dambimangari, R. (2012). Developing Boat-Based Survey Methods for Dugong and Marine Turtles: Field Trials at Montgomery Reef, Western Australia, August 2012. NAILSMA Knowledge Series 021/2013. North Australian Indigenous Land and Sea Management Alliance Ltd, Darwin.

Jarvis, D. I., Padoch, C., \& Cooper, H. D. (2007). Biodiversity, agriculture and ecosystem services. In D. I. Jarvis, C. Padoch and D. Cooper (Eds.), Managing Biodiversity in Agricultural Ecosystems (pp. 1-12). Columbia University, New York, USA. https://doi.org/10.7312/jarv13648-003

Legesse, A., Teferi, B., \& Baudouin, A. (2013). Indigenous agroforestry knowledge transmission and young people's participation in agroforestry practices: The case of Wonago Woreda, Gedeo Zone, South Ethiopia. Retrieved November 10, 2015, from http://www.svt.ntnu.no/geo/Doklager/Acta/SerieA_26_Abiyot-BogaleBaudouin.pdf

Megersa, G. (2014). Genetic erosion of barley in North Shewa Zone of Oromiya Region, Ethiopia. International Journal of Biodiversity and Conservation, 6, 280-289. https://doi.org/10.5897/IJBC2013.0673

Mijatovic, D., Van Oudenhoven, F., Eyzaguirre, P., \& Hodgkin, T. (2013). The role of agricultural biodiversity in strengthening resilience to climate change: Towards an analytical framework. International Journal of Agricultural Sustainability, 11, 95-107. https://doi.org/10.1080/14735903.2012.691221

Ogunbode, C. A., \& Arnold, K., (2012). A Study of Environmental Awareness and Attitudes in Ibadan, Nigeria. Human and Ecological Risk Assessment: An International Journal, 18(3), 669-684. https://doi.org/10.1080/ 10807039.2012.672901

Osawa, M. (2014). Contemporary discourses on agriculture in Japan: From futureless 3K to sophisticated future lifestyle in LOHAS, living in rural areas, and Hannō Han-x. Bulletin of the Graduate Division of Literature of Waseda University, 4, 111-121. 
Paroda, R. S., \& Arora, R. K. (1991). Plant Genetic Resources: General Perspective. In R. S. Paroda \& R. K. Arora (Eds.), Plant Genetic Resources Conservation and Management (pp. 1-23). New Delhi: International Board for Plant Genetic Resources Regional Officer for South and Southeast Asia.

Poudel, D., Rijal, D., Johnsen, F. H., Synnevag, G., \& Subedi, A. (2004). Conservation of crop genetic resources in community genebank: Farmers' willingness to pay for conservation of rice landraces in Kaski, Nepal. On-farm conservation of agricultural biodiversity in Nepal Volume II, managing diversity and promoting its benefits. Proceedings of the Second National Workshop 25-27 August 2004, Nagarkot, Nepal.

Pradhan, B. (1984). Gender and Rice Farming in Nepal. Proceedings of a Conference on Women in Rice Farming Systems, September 26-30, 1983, IRRI, Philippines.

Rana, R. B., Garforth, C. J., Sthapit, B. R., Subedi, A., Chaudhary, P., \& Jarvis, D. I. (2007). On-farm management of rice genetic diversity: Understanding farmers' knowledge on rice ecosystems and varietal deployment. Plant Genetic Resources Newsletter, 152, 58-64.

Rana, R. B., Garforth, C., Sthapit, B., \& Jarvis, D. (2007). Influence of socio-economic and cultural factors in rice varietal diversity management on-farm in Nepal. Agriculture and Human Values, 24, 461-472. https://doi.org/10.1007/s10460-007-9082-0

Regidor, J. G. (2012). EU measures to encourage and support new entrants. Brussels: European Parliament.

Ribot, J. C. (2010). Vulnerability does not just fall from the sky: Toward multi-scale pro-poor climate policy. In R. Mearns and A. Norton (Eds.), Social dimensions of climate change: Equity and vulnerability in a warming world (pp. 47-74). Washington, DC: The World Bank.

Sahai, S. (2003). Indigenous Knowledge and Its Protection in India. Trading in Knowledge (pp. 184-189). Earthscan, London.

Singh, A., Singh, R. K., \& Sureja, A. K. (2007). Cultural significance and diversities of ethnic foods of Northeast India. Indian Journal of Traditional Knowledge, 6, 79-94.

Sthapit, B., Shrestha, P., \& Upadhyay, U. P. (2005). Diversity Block: Assessing and Demonstrating Local Crop Diversity. On-farm Management of Agricultural Biodiversity in Nepal (p. 80). NARC, LI-BIRD and IPGRI, Nepal.

Subedi, A., Chaudhary, P., Baniya, B. K., Rana, R.B., Tiwari, R. K., Rijal, D. K., ... Jarvis, D. I. (2003). Who maintains genetic diversity and how? Implications for on-farm conservation and utilization. Culture and Agriculture, 25, 41-45. https://doi.org/10.1525/cag.2003.25.2.41

Subedi, A., Gauchan, D., Chaudhary, P., Rana, R. B., Rijal, D. K., \& Tiwari, R. K. (2003). Gender and decision-making roles in agrobiodiversity management and conservation in mid-hill and terai villages of Nepal. In B. Sthapit, M. P. Upadhyay, B. K. Baniya, A. Subedi, \& B. K. Joshi (Eds.), On-farm management of agricultural biodiversity in Nepal. Proceedings of a National Workshop, Lumle, Nepal.

Turner, N. J., \& Clifton, H. (2009). "It's so different today": Climate change and indigenous lifeways in British Columbia, Canada. Global Environmental Change, 19, 180-90. https://doi.org/10.1016/j.gloenvcha.2009. 01.005

UNEP (United National Environment Programme). (2008). Farmers and the future of agro-biodiversity. Bonn, Germany. Retrieved from http://www.unep.org/chinese/iyb/pdf/Agrobiodivbriefs.pdf

Vanek, S. J., \& Drinkwater, L. E. (2013). Environmental, social, and management drivers of soil nutrient mass balances in an extensive Andean cropping system. Ecosystems, 16, 1517-1535. https://doi.org/10.1007/ s10021-013-9699-3

Vealdi, M. D. (2008). Report on the future for Young Farmers under the ongoing reform of CAP. Committee on Agriculture and Rural Development.

WIPO. (2009). Intergovernmental Committee on Intellectual Property and Genetic Resources, Traditional Knowledge and Folklore, Secretariat. Report Fourteenth Session (WIPO/GRTKF/IC/14/12).

Zimmerer, K. S. (2013). The compatibility of agricultural intensification in a global hotspot of smallholder agrobiodiversity (Bolivia). Proceedings of the National Academy of Sciences of the United States of America, 110(8), 2769-2774. https://doi.org/10.1073/pnas.1216294110 


\section{Notes}

Note 1. Diversity block is an experimental block of farmers' varieties grown in non-replicated plot on-farm, which is maintained to assess, characterize and demonstrate the value of local crop diversity (Sthapit et al., 2005).

\section{Copyrights}

Copyright for this article is retained by the author(s), with first publication rights granted to the journal.

This is an open-access article distributed under the terms and conditions of the Creative Commons Attribution license (http://creativecommons.org/licenses/by/4.0/). 